Research Paper

\title{
Titanium Dioxide Nanoparticles as Radiosensitisers: An In vitro and Phantom-Based Study
}

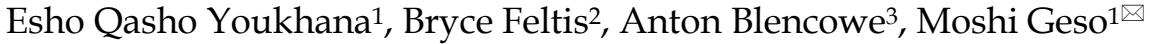 \\ 1. Discipline of Medical Radiations, School of Health and Biomedical Sciences, RMIT University, Bundoora, Victoria, Australia; \\ 2. Pharmaceutical Sciences Discipline, School of Health and Biomedical Sciences, RMIT University, Bundoora, Victoria, Australia; \\ 3. School of Pharmacy and Medical Science, Division of Health Sciences, The University of South Australia, Adelaide, SA 5000, Australia \\ $\bowtie$ Corresponding author: A/Prof Moshi Geso, Tel: +61401730320, Email: moshi.geso@rmit.edu.au \\ (c) Ivyspring International Publisher. This is an open access article distributed under the terms of the Creative Commons Attribution (CC BY-NC) license \\ (https://creativecommons.org/licenses/by-nc/4.0/). See http://ivyspring.com/terms for full terms and conditions.
}

Received: 2017.01.05; Accepted: 2017.03.29; Published: 2017.05.15

\begin{abstract}
Objective: Radiosensitisation caused by titanium dioxide nanoparticles ( $\left.\mathrm{TiO}_{2}-\mathrm{NPs}\right)$ is investigated using phantoms (PRESAGE ${ }^{\circledR}$ dosimeters) and in vitro using two types of cell lines, cultured human keratinocyte ( $\mathrm{HaCaT})$ and prostate cancer (DU145) cells.

Methods: Anatase $\mathrm{TiO}_{2}-\mathrm{NPs}$ were synthesised, characterised and functionalised to allow dispersion in culture-medium for in vitro studies and halocarbons (PRESAGE ${ }^{\circledR}$ chemical compositions). PRESAGE ${ }^{\circledR}$ dosimeters were scanned with spectrophotometer to determine the radiation dose enhancement. Clonogenic and cell viability assays were employed to determine cells survival curves from which the dose enhancement levels "radiosensitisation" are deduced.

Results: Comparable levels of radiosensitisation were observed in both phantoms and cells at kilovoltage ranges of $x$-ray energies (slightly higher in vitro). Significant radiosensitisation ( 67\%) of control was also noted in cells at megavoltage energies (commonly used in radiotherapy), compared to negligible levels detected by phantoms. This difference is attributed to biochemical effects, specifically the generation of reactive oxygen species (ROS) such as hydroxyl radicals $(\cdot \mathrm{OH})$, which are only manifested in aqueous environments of cells and are non-existent in case of phantoms.

Conclusions: This research shows that $\mathrm{TiO}_{2}-\mathrm{NPs}$ improve the efficiency of dose delivery, which has implications for future radiotherapy treatments. Literature shows that $\mathrm{Ti}_{2} \mathrm{O}_{3}-\mathrm{NPs}$ can be used as imaging agents hence with these findings renders these NPs as theranostic agents.
\end{abstract}

Key words: Titanium dioxide, Nanoparticles, Reactive oxygen species, Radiosensitisation.

\section{Introduction}

There have been various advancements in the field of radiotherapy resulting in safer and more reliable treatments [1]. Most of these developments have been technological improvements used to confine the beams to the targets and reduce radiation damage to the surrounding healthy tissues [2]. However, these technological improvements can also be combined with an advanced understanding of tumour radiobiology to provide the greatest impact on treatment regimens $[3,4]$. Thus, improving the efficiency of radiotherapy treatments requires a combination of these complementary approaches, such as the use of radiosensitisation agents [4].

Tumour radiosensitivity can be modified by agents, which enhance the radiation effects in the tumour, with the objective of delivering efficient radiation doses that can eradicate cancer cells without exceeding normal tissue tolerances [5]. In many cases the radiosensitising agents can selectively target tumour cells [4]. Currently, some radiosensitising agents, such as fluorouracil are used clinically particularly in adjuvant radiotherapy treatments [4].

Early investigations used high atomic number (Z) materials [4], such as gold with the aim of increasing the cross-sectional radiation interaction and production of free radicals, which enhances radiation dose through extra photoelectron production [6-11]. As the increase in cross-sectional 
interaction is mainly due to the increased photoelectric effect's probability of occurrence (PE), but only significantly with low energy $\mathrm{X}$-rays, where the probability of PEs are high. However, very few investigations have been conducted into the dose enhancement effects provided by low $\mathrm{Z}$ materials which are generally less toxic.

Studies have shown that upon irradiation, anatase $\mathrm{TiO}_{2}-\mathrm{NPs}$ generate free radicals that facilitate the spontaneous generation of reactive oxygen species (ROS), which can damage nucleic acids (e.g., DNA) [12-15]. Interestingly, this behaviour has not been observed with rutile $\mathrm{TiO}_{2}-\mathrm{NPs}$ [4]. A correlation between the $\mathrm{TiO}_{2}-\mathrm{NP}$ size and ROS activity has been noted, whereby an increase in ROS was observed for $\mathrm{TiO}_{2}-\mathrm{NPs}$ of up to $30 \mathrm{~nm}$ in diameter and then remained constant for larger particle sizes [16]. It has also been reported that increasing the mole fraction of oxygen atoms by inclusion of Ti-peroxide can also improve radiosensitisation efficiency [16]. In all cases, these studies were conducted with low energy X-rays, which are of very limited use in clinical radiotherapy. Others have shown that titanium dioxide and titanium nanotubes can penetrate human glioblastoma cells in vitro and stay in the cytosol for over 10 days without inducing cytotoxicity or decreasing DNA repair efficiency after irradiation with a linear accelerator [4]. In vivo studies using rare earth doped $\mathrm{TiO}_{2}-\mathrm{NPs}$ have demonstrated significant tumour volume decreases when irradiated with 200 $\mathrm{kV}$ X-rays [14]. Collectively, all these investigations used UV radiation, gamma radiation and/or low energy X-ray beams.

In this study, we demonstrate the potential of $\mathrm{TiO}_{2}$-NPs for the enhancement of clinically relevant megavoltage (MV) radiotherapy beams. Anatase $\mathrm{TiO}_{2}$-NPs with an average diameter of $30 \mathrm{~nm}$ were prepared and studied in vitro using cell culture and phantoms. $\mathrm{TiO}_{2}-\mathrm{NPs}$ proved to be cytocompatible to cells, even at very high concentrations. However, concurrent megavoltage irradiation resulted in significant radiosensitisation of the cells, which is proposed to result from the generation of free radicals and increased ROS. Specifically, prostate cancer (DU145) and keratinocyte (HaCaT) cell lines were incubated with $\mathrm{TiO}_{2}$-NP at concentrations ranging from $0.5-4 \mathrm{mM}$, and following megavoltage irradiation, significant radiosensitisation was achieved for both DU145 (14-67\%) and HaCaT (9-50\%) cell lines at $80 \%$ cell survival. It should be noted that the terms radiosensitisation and dose enhancement are used interchangeably throughout this manuscript. $\mathrm{TiO}_{2}-\mathrm{NPs}$ has also been documented to be suitable as diagnostic agent through its ability to enhance the subject contrast [14], hence this nano-compound qualifies to be true theranostic agent.

\section{Materials and Methods}

\section{Synthesis of Anatase Crystalline Phase $\mathrm{TiO}_{2}$-NPs}

Anatase $\mathrm{TiO}_{2}-\mathrm{NPs}$ were synthesised in accordance with a previously published procedure [17]. Briefly, sulfuric acid $\left(15 \mathrm{~mL}, 10 \% \mathrm{H}_{2} \mathrm{SO}_{4}\right)$ was added to Milli $Q$ water $(150 \mathrm{~mL})$ and cooled to $0{ }^{\circ} \mathrm{C}$ in an ice-water bath. $\mathrm{TiCl}_{4}(10 \mathrm{~mL})$ was slowly added to the solution with vigorous stirring, and after $30 \mathrm{~min}$, the mixture was heated to $85^{\circ} \mathrm{C}$ for $1 \mathrm{~h}$. The $\mathrm{pH}$ was adjusted to 7 via the drop-wise addition of concentrated ammonia (30\%) and the solution was cooled to room temperature and allowed to stand for $12 \mathrm{~h}$. The resulting $\mathrm{TiO}_{2}-\mathrm{NPs}$ were washed with Milli $Q$ water $(2 \times 15 \mathrm{~mL})$ and isolated via centrifugation (5000 rcf, $5 \mathrm{~min}$ ), followed by drying $\left(80{ }^{\circ} \mathrm{C}, 500\right.$ mbar). The dried $\mathrm{TiO}_{2}-\mathrm{NPs}$ were calcinated at $600{ }^{\circ} \mathrm{C}$ for $2 \mathrm{~h}$ to produce a bright white powder.

\section{Surface Modification of $\mathrm{TiO}_{2}-\mathrm{NPs}$}

Two types of $\mathrm{TiO}_{2}$-NPs were prepared with different surface modifications. Aminopropyl trimethoxysilane (APTS) modified NPs (i.e., amine functionalised $\mathrm{TiO}_{2}-\mathrm{NPs}$ ) [18-20] were prepared to allow aqueous dispersion for cell studies. Poly(ethylene glycol) trimethoxysilane (PEGTS) modified NPs (i.e., PEG functionalised $\mathrm{TiO}_{2}-\mathrm{NPs}$ ) [4] were prepared to allow dispersion in halocarbons for incorporation into PRESAGE $^{\circledR}$ formulations. The preparation procedures for these coatings are described in the Supplementary information.

Amine functionalised $\mathrm{TiO}_{2}-\mathrm{NPs}$ : Bare $\mathrm{TiO}_{2}-\mathrm{NPs}$ (200 mg) were suspended in toluene $(10 \mathrm{~mL})$ with sonication in a flask complete with a stirrer bar, then APTS $(200 \mu \mathrm{L})$ and butylamine $(50 \mu \mathrm{L})$ were added. The flask was sealed and the mixture was heated at 50 ${ }^{\circ} \mathrm{C}$ for $2 \mathrm{~h}$ with constant stirring. After cooling to room temperature, the NPs were isolated via centrifugation (2000 rcf, $30 \mathrm{~s}$ ) and then resuspended in isopropanol $(40 \mathrm{~mL})$ containing concentrated hydrochloric acid $(0.2 \mathrm{~mL})$. The NPs were again isolated via centrifugation (2500 rcf, $180 \mathrm{~s})$ and then resuspended in isopropanol $(10 \mathrm{~mL})$. This last washing step was repeated once more, and the amine functionalised $\mathrm{TiO}_{2}-\mathrm{NPs}$ were isolated after drying in air for $12 \mathrm{~h}$.

PEG functionalised $\mathrm{TiO}_{2}-\mathrm{NPs}$ : Bare $\mathrm{TiO}_{2}-\mathrm{NPs}$ $(200 \mathrm{mg})$ were suspended in toluene $(10 \mathrm{~mL})$ with sonication in a flask complete with a stirrer bar, then PEGTS $(200 \mu \mathrm{L})$ and butylamine $(50 \mu \mathrm{L})$ were added. The flask was sealed and the mixture was heated at 50 ${ }^{\circ} \mathrm{C}$ for $6 \mathrm{~h}$ with constant stirring. After cooling to room temperature, the NPs were isolated via centrifugation 
(2000 rcf, $30 \mathrm{~s}$ ) and then resuspended in isopropanol $(40 \mathrm{~mL})$. The PEG functionalised $\mathrm{TiO}_{2}-\mathrm{NPs}$ were then isolated via centrifugation (2500 rcf, $180 \mathrm{~s}$ ) and air dried for $12 \mathrm{~h}$.

\section{Characterisation of $\mathrm{TiO}_{2}-\mathrm{NPs}$}

Transmission electron microscopy (TEM) was performed with a Jeol 1010 microscope (100 KeV) equipped with Gatan Orius SC600 CCD-2014 camera, and was used to determine NP size distributions. $\mathrm{TiO}_{2}-\mathrm{NP}$ samples were prepared by dispersion in ethanol $(0.1 \mathrm{mg} / \mathrm{mL})$ with sonication for $180 \mathrm{~s}$, and then a drop of the suspension was deposited onto a GYCu200 mesh copper holey carbon (25ct) and/or GSCu200C-50 strong carbon TEM grids. More than 100 individual NPs were measured to determine average particle diameter. X-ray photoelectron Spectrometry (XPS) was performed on a Thermo $\mathrm{K}$-alpha X-ray spectrometer, and was used to analyse the chemical composition of the NPs. X-ray diffraction (XRD) spectroscopy was performed on a Bruker Axs D8 ADVANCE spectrometer, and was used to determine the crystalline phase of the NPs. Thermogravimetric analysis (TGA) was performed on a Perkin Elmer Hyphenated Pyris 1 instrument, and was used to study the NP coating characteristics. Fourier transform infrared (FTIR) spectroscopy was performed on a BRUKER TENSOR 27 spectrometer, where $\mathrm{TiO}_{2}-\mathrm{NPs}$ were impregnated in $\mathrm{KBr}$ discs and was used to study the chemical composition of the NP coatings.

\section{Phantom (PRESAGE ${ }^{\circledR}$ Dosimeter) Fabrication}

The PRESAGE ${ }^{\circledR}$ dosimeters were formulated using the following ingredients: polyurethane prepolymer (Crystal Clear 200, $48.9 \mathrm{wt} \%$ part A and $44 \mathrm{wt} \%$ part B; Smooth-On, Easton, PA, USA), $2 \mathrm{wt} \%$ leuco dye (leucomalachite green-LMG) as a reporter component, $0.1 \mathrm{wt} \%$ dibutyltin dilaurate (DBTDL) and $5 \mathrm{wt} \%$ chloroform (Sigma Aldrich-St Louis, MO) was used as a halocarbon radical initiator. PEG functionalised $\mathrm{TiO}_{2}$-NPs were homogenously dispersed in chloroform with sonication to afford final $\mathrm{NP}$ concentrations of $0,0.5,1$ and $4 \mathrm{mM}$ in the dosimeters. PRESAGE ${ }^{\circledR}$ dosimeters were fabricated according to previously described procedures [4]. The final prepared solution was then poured into cuvettes which were then placed in a chamber (pressure pot) under pressure (ca. 60 psi) for 48 hours for curing. This was done in order to eliminate the formation of air bubbles inside the dosimeters as a result of outgassing [4].

\section{Phantom Irradiation}

Irradiation was carried out using both kilovoltage $(\mathrm{kV})$ and megavoltage (MV) X-ray beams at the Alfred Health Radiation Oncology Department (The Alfred Hospital, Melbourne, Australia). For kilovoltage energies, the dosimeter were irradiated with an $80 \mathrm{kV}$ beam from superficial X-ray therapy (SXRT) machine (Therapax 3 Series, Pantak Inc., Branford, CT, USA) at radiation doses ranging from 0-25 Gy. The radiation was delivered as a single fraction with a dose rate of $1.090 \mathrm{~Gy} / \mathrm{min}$ using a 15 $\mathrm{cm}$ diameter collimator with filter 5 and $2.2 \mathrm{~mm} \mathrm{Al}$ HVL. The distance from the X-ray source to the surface of cuvettes was fixed at $25 \mathrm{~cm}$. Megavoltage irradiation was performed using a $6 \mathrm{MV}$ X-ray beam from a medical linear accelerator (LINAC, Clinic 21EX, Varian Associates Inc., CA, USA). The cuvettes were surrounded with solid water (water equivalent plastic phantom) to provide a full scatter environment with $10 \mathrm{~cm}^{2}$ field size and a $100 \mathrm{~cm}$ source-surface-distance (SSD). In addition, the cuvettes were placed at the centre of the beam to ensure all samples received a uniform radiation dose and a $5 \mathrm{~cm}$ solid water phantom layer was placed on top of the cuvettes so that a maximal and uniform dose was delivered to the phantoms. A single fraction irradiation was delivered to the dosimeter at a constant dose rate of $600 \mathrm{MU} / \mathrm{min}$ with radiation doses ranging from 0-25 Gy. The irradiation setup for both kilovoltage and megavoltage $\mathrm{X}$-ray beams is shown in Figure 1.

\section{Optical Density (OD) Measurements}

UV-Vis spectrophotometry was performed on a dual-beam Perkin Elmer Lambda 25 UV-VIS spectrophotometer (Perkin Elmer, Waltham, MA, USA), and was used to measure changes in optical density $(\triangle \mathrm{OD})$ of the dosimeter cuvettes at an absorption maxima of $\lambda=633 \mathrm{~nm}[21,22]$.

\section{Cell Culture}

In this study, human keratinocyte (HaCaT) and prostate (DU145) cell lines were used. HaCaT and DU145 cells were cultured in RPMI medium 1640 (1X) and MEM (Gibco by Life Technologies Pty. Ltd., Mulgrave, VIC, Australia) supplemented with $5 \%$ and $10 \%$ heat inactivated fetal bovine serum (FBS, In Vitro Technology Pty. Ltd., Noble Park, VIC, Australia), respectively, and $1 \%$ penicillin streptomycin (Gibco by Life Technologies Pty. Ltd., Mulgrave, VIC, Australia). Cells were grown in 75 $\mathrm{cm}^{2}$ flasks (Sigma-Aldrich Pty. Ltd., St Louis, Mo, USA) and subcultured at approximately $80 \%$ confluency. The cells were incubated in a humidified atmosphere at $37{ }^{\circ} \mathrm{C}, 5 \% \mathrm{CO}_{2}$. Cells in passages $4-12$ were used in this research. 


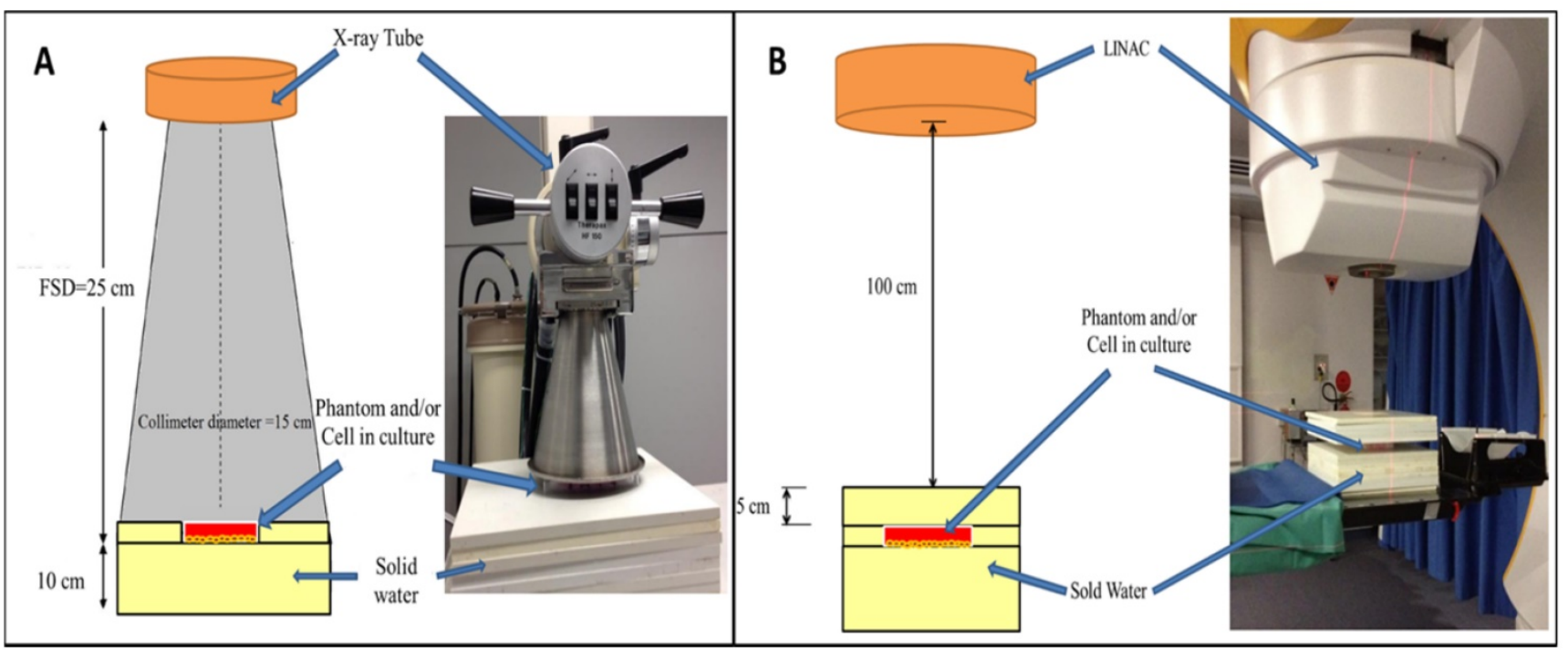

Figure 1. Illustrations showing setup used for irradiation of phantoms and/or cells in culture: A) kilovoltage irradiation setup and, B) megavoltage irradiation setup. Illustrations not to scale. Insets: digital images showing SXRT and LINAC instruments.

For experiments with $\mathrm{TiO}_{2}-\mathrm{NPs}$, the dried NP power was dispersed in either RPMI medium 1640 (1X) or MEM for HaCaT and DU145 cells, respectively, to provide concentrations ranging from 1-30 mM. The resulting solutions were filtered through a $0.22 \mu \mathrm{m}$ polysulfonic membranes (Sartorius, Goettingen, Germany), sonicated for 30 min and then used in cell studies.

\section{$\mathrm{TiO}_{2}-\mathrm{NPs}$ Association with Cells}

HaCaT cells were seeded in 24-well culture plates with a total of $1.5 \times 10^{4}$ cells per well and incubated at $37^{\circ} \mathrm{C}$ and $5 \% \mathrm{CO}_{2}$. After $24 \mathrm{~h}$ incubation the cells were exposed to amine functionalised $\mathrm{TiO}_{2}-\mathrm{NP}$ concentrations of $0.5,1$ and $4 \mathrm{mM}$ for $24 \mathrm{~h}$. Subsequently, the culture medium was removed and the cells were rinsed with PBS and harvested using $0.05 \%$ trypsin-EDTA (1X) (Gibco by Life Technologies Pty. Ltd., Mulgrave, VIC, Australia). The solution was centrifuged at $300 \mathrm{~g}$ for $5 \mathrm{~min}$ and the cells were resuspended in PBS $(2 \mathrm{~mL})$. The uptake of $\mathrm{TiO}_{2}-\mathrm{NPs}$ by $\mathrm{HaCaT}$ cells was determined by flow cytometry (FACS Canto II, BD Biosciences). 10,000 gated events were counted and forward and side-scatter were recorded. Changes in side-scatter were assessed relative to an untreated control cell population.

\section{Cytotoxicity of $\mathrm{TiO}_{2}-\mathrm{NPs}$}

HaCaT and DU145 cells were seeded into 24 -well plates at a density of $3 \times 10^{4}$ cells per well. Cells were then incubated for $24 \mathrm{~h}$ at $37^{\circ} \mathrm{C}$ and $5 \% \mathrm{CO}_{2}$, and then treated with amine functionalised $\mathrm{TiO}_{2}-\mathrm{NP}$ solutions in culture media at concentrations ranging from 0-30 mM. A tetrazolium dye-based cell viability assay (CellTiter 96® AQueous One Solution Cell
Proliferation, Promega Corp., Madison, WI, U.S.A.) was utilized to assess the cytotoxicity of $\mathrm{TiO}_{2}-\mathrm{NPs}$ [23]. Cytotoxicity was measured at 24, 48 and $72 \mathrm{~h}$ after $\mathrm{TiO}_{2}-\mathrm{NP}$ addition. In this preliminary assay, cells were not exposed to any radiation. Measurements of cell viability were used to determine $\mathrm{TiO}_{2}-\mathrm{NP}$ cytocompatibility.

\section{Cell Irradiation}

The irradiation methodology for cells followed the design/set-up, energies and procedures previously detailed in the phantom irradiation section. The radiation doses used for cells ranged from 0-8 Gy. The irradiation setup is shown in Figure 1.

\section{Cell Survival Assays}

Two methods were implemented for cell survival measurements

MTS survival assay: MTS(3-(4,5-dimethylthiazol2-yl)-5-(3-carboxymethoxyphenyl)-2-(4-sulfophenyl)$2 \mathrm{H}$-tetrazolium) assays were employed to obtain cell survival curves using a CellTiter 96® AQueous One Solution Cell Proliferation Assay (Promega Corp., Madison, WI, USA). Cells were seeded in 96-well plates at a density of $3 \times 10^{3}$ cells per well and incubated at $37{ }^{\circ} \mathrm{C}, 5 \% \mathrm{CO}_{2}$ for $18 \mathrm{~h}$. The culture media was removed, and the cells were treated with 0 , $0.5,1$ and $4 \mathrm{mM}$ of amine functionalised $\mathrm{TiO}_{2}-\mathrm{NPs}$ (200 $\mu \mathrm{L}$ in fresh media) for $24 \mathrm{~h}$. The culture medium was changed and the cells were then irradiated with $\mathrm{kV}$ and MV energies according to the specifications previously stated. After irradiation, cells were incubated for $24 \mathrm{~h}$, and the media was changed and then incubated for a further $48 \mathrm{~h}$. Subsequently, the 
medium was removed and $300 \mu \mathrm{L}$ of culture medium and $60 \mu \mathrm{L}$ of CellTiter $96^{\circledR}$ AQueous One Solution Cell Proliferation Assay reagent were added. The assay is light sensitive and therefore, cell culture plates were wrapped with aluminium foil upon incubation. A CLARIOstar microplate reader (BMG LABTECH Inc, Ortenberg, Germany) was used for measuring the absorbance (optical density) of the solutions at a wavelength of $490 \mathrm{~nm}$. The absorbance was recorded directly after adding the MTS (for background subtraction), and again after $40 \mathrm{~min}$ incubation period. Measurements are expressed as a percentage relative to the negative control cells:

Surviving fraction $=\frac{\text { Absorbance of irradiated cells }- \text { Background }}{\text { Absorbance of control cells }- \text { Background }} \times 100 \%$

Clonogenic survival assay: After counting, cells were seeded in 6-well plates at various densities (Table 1) and incubated at $37{ }^{\circ} \mathrm{C}, 5 \% \mathrm{CO}_{2}$ for $18 \mathrm{~h}$. Cells were treated with amine functionalised $\mathrm{TiO}_{2}-\mathrm{NPs}$ and irradiated in an identical procedure to that described in the MTS assay. After $14 \mathrm{~d}$ incubation, the cells were then fixed in (1:7) oleic acid/ethanol solution for $5 \mathrm{~min}$ and stained with a 0.5 $\%$ crystal violet in ethanol solution for $15 \mathrm{~min}$. The plates were then gently washed with water to prevent the colonies from loosening and washing off and allowed to dry overnight. The colonies were digitally scanned using a Leica DMD 108 digital micro-imaging instrument (Leica Microsystems CMS $\mathrm{GmbH}$ manufacture, Mannheim, Germany), and counted manually.

Table 1. HaCaT and DU145 cell seeding densities in 6-well plates for clonogenic survival assays at specified doses.

\begin{tabular}{lll}
\hline Dose (Gy) & \multicolumn{2}{l}{ Density of seeded cells in 6-well plates (cells/well) } \\
\cline { 2 - 3 } & HaCaT & DU145 \\
\hline 0 & 150 & 250 \\
1 & 250 & 500 \\
2 & 250 & 750 \\
3 & 500 & 1000 \\
4 & 500 & 1500 \\
5 & 750 & 2000 \\
6 & 750 & 2500 \\
8 & 1000 & 3000 \\
\hline
\end{tabular}

\section{In vitro Detection of ROS}

The 2', $7^{\prime}$-Dichlorofluorescin diacetate (DCFDA) (Sigma-Aldrich Pty. Ltd., St Louis, Mo, USA) was dissolved in dimethyl sulfoxide (DMSO) at a concentration of $100 \mu \mathrm{M}$, and stored at $-20{ }^{\circ} \mathrm{C}$ in the dark. Immediately before use, the DCFDA solution was diluted 1:1000 in PBS (phosphate buffered saline). Black 96 well plates were used in this experiment, with total solution volumes of $200 \mu \mathrm{L}$ per well $(100 \mu \mathrm{L}$ DCFDA solution). Various concentrations of amine functionalised $\mathrm{TiO}_{2}$-NPs $(0.5,1$ and $4 \mathrm{mM}$ ) were prepared in $100 \mu \mathrm{L}$ PBS. The samples were irradiated with $6 \mathrm{MV}$ X-ray beams from an ELECTA LINAC at doses of 15 or $40 \mathrm{~Gy}$. The nonfluorescent DCFDA is converted to highly fluorescent product post-oxidisation in the presence of ROS. The total fluorescence of the samples was measured using a CLARIOstar microplate reader with excitation and emission wavelengths of 483 and $530 \mathrm{~nm}$, respectively. All fluorescence measurements were performed in the dark and at room temperature.

\section{Statistical Analysis}

All data represents the mean of three independent experiments. Results are reported as mean \pm SEM. Statistical analysis was performed using OriginPro 2016 SR1 v9.3.1.273 software. Two-way analysis of variance (ANOVA) was applied to determine significance, followed by a Tukey test for post-hoc comparisons when significance was indicated. Results were considered to be statistically significant at $p$ values of less than $0.05\left({ }^{*} p<0.05,{ }^{* *} p\right.$ $<0.01,{ }^{* * *} \mathrm{p}<0.001$ ).

\section{Results}

\section{Characterisation of Functionalised $\mathrm{TiO}_{2}-\mathrm{NPs}$}

$\mathrm{TiO}_{2}-\mathrm{NPs}$ were synthesised via a chemical hydrolysis method as previously reported [17]. TEM revealed $\mathrm{TiO}_{2}-\mathrm{NPs}$ to be spherical with a mean diameter of $30 \pm 5 \mathrm{~nm}$ (Figures $2 \mathrm{~A}$ and $\mathrm{B}$ ). X-ray diffraction $(X R D)$ patterns of the $\mathrm{TiO}_{2}-\mathrm{NPs}$ revealed a primary peak at $25.32 \theta$ (degrees) and numerous smaller peaks that confirmed the $\mathrm{TiO}_{2}$ anatase structure with a $84.6 \%$ crystal phase (Figure 2C) [17]. The elemental composition of the $\mathrm{TiO}_{2}$-NPs was determined via X-ray photoelectron spectroscopy (XPS), which revealed peaks with characteristic binding energies for titanium and oxygen (Figure 2D). The additional peak for carbon was used to calibrate the relative energies and all peaks are in agreement with previous studies [17].

Subsequently, the bare $\mathrm{TiO}_{2}-\mathrm{NPs}$ were functionalised through silanization with either 3-aminopropyl trimethoxysilane (APTS) or poly (ethylene glycol) propyl trimethoxysilane (PEGTS) to afford amino- and PEG-functionalised NPs that could be easily dispersed in aqueous and organic solutions, respectively (Figure 3 ). 
A

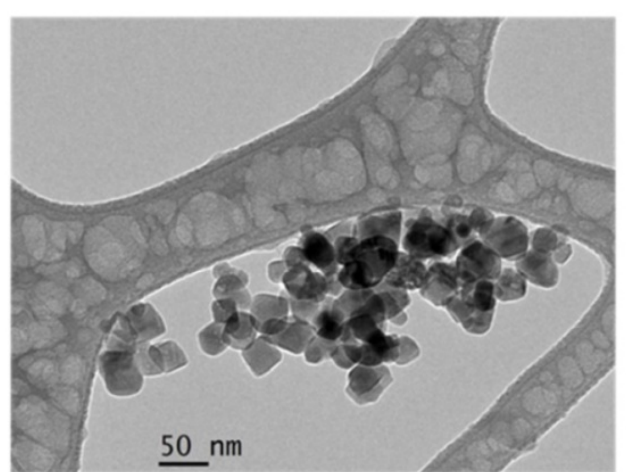

C

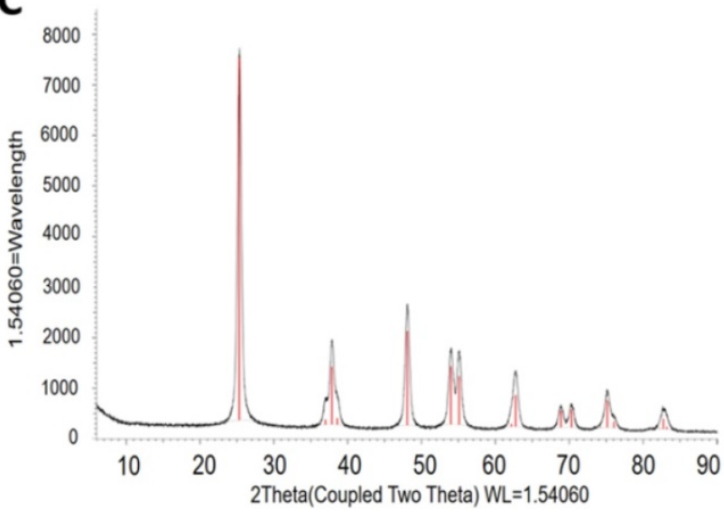

B

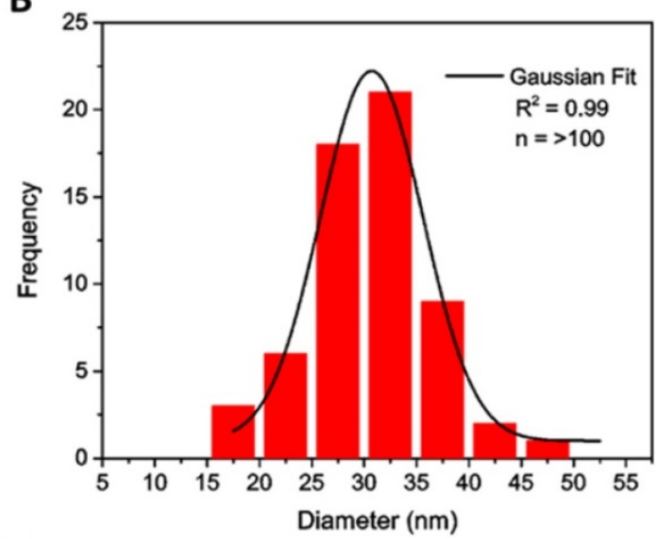

D

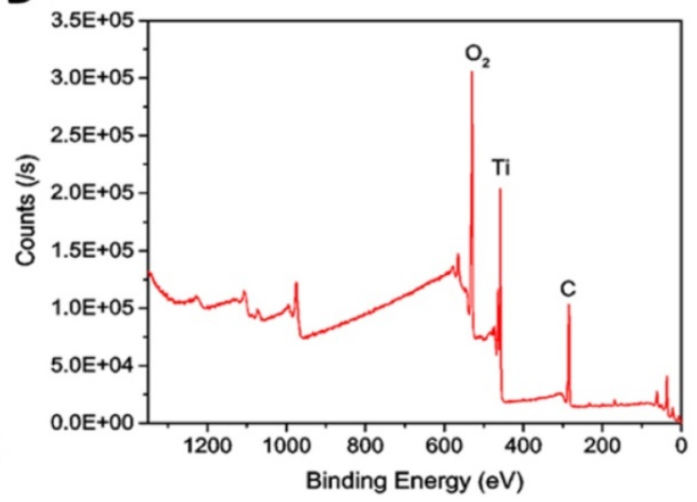

Figure 2. A) TEM image of $\mathrm{TiO}_{2}-\mathrm{NPs}$ (scale bar $50 \mathrm{~nm}$ ). B) Size distribution of $\mathrm{TiO}_{2}-\mathrm{NPs}$ from TEM images. C) XRD. D) XPS spectra of TiO ${ }_{2}-\mathrm{NPs}$.

In comparison with bare $\mathrm{TiO}_{2}-\mathrm{NPs}$, TGA analysis of the amine- and PEG-functionalised $\mathrm{TiO}_{2}-\mathrm{NPs}$ revealed $\sim 5 \mathrm{wt} \%$ loss over temperature ranges of 270-550 ${ }^{\circ} \mathrm{C}$, which is attributed to the decomposition of the organic coating (Figure 4A). Fourier transform infrared spectroscopy (FTIR) of the bare and functionalised $\mathrm{TiO}_{2}$-NPs showed a typical $\mathrm{TiO}_{2}$ pattern ranging between $500 \sim 700 \mathrm{~cm}^{-1}$, which is attributed to Ti-O-Ti vibrations in the $\mathrm{TiO}_{2}$ lattice [17]. The absorption peak at $1639 \mathrm{~cm}^{-1}$ and the broad band at $3344 \mathrm{~cm}^{-1}$ in all samples are attributed to the surface hydroxyl groups $(\mathrm{OH})$ present in the $\mathrm{TiO}_{2}-\mathrm{NPs}$ (Figure 4B (a, b, c)) [17]. The band at 993 $\mathrm{cm}^{-1}$ (Ti-O-Si) confirms the condensation reactions between the methoxy groups of APTS and the $\mathrm{TiO}_{2}-\mathrm{NPs}$ surface hydroxyl groups has occurred (Figure 4B, (c)) [17]. The peak at $1047 \mathrm{~cm}^{-1}$ is due to the (Si-O-Si) asymmetric vibrations indicating occurrence of condensation reaction with the silanol groups (Figure 4B, (c)) [17]. The peaks at $\sim 1130 \mathrm{~cm}^{-1}$ for the amine and PEG functionalised $\mathrm{TiO}_{2}-\mathrm{NPs}$ are consistent with $\mathrm{C}-\mathrm{N}$ and $\mathrm{C}-\mathrm{O}$ vibrations, respectively, which demonstrate successful grafting to the surface of the modified nanoparticles [17]. Peaks at $1384 \mathrm{~cm}^{-1}$ and $2931 \mathrm{~cm}^{-1}$ in all samples were attributed to the asymmetrical C-H vibrations [17].
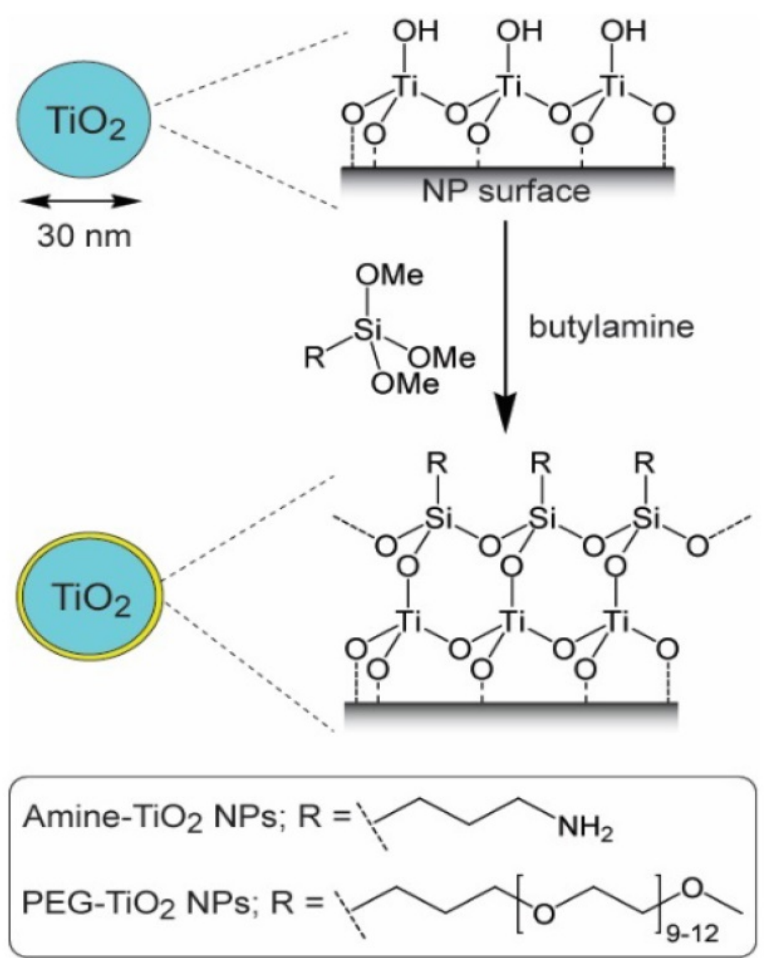

Figure 3. Surface modification of $\mathrm{TiO}_{2}-\mathrm{NPs}$ via silanisation with APTS and PEGTS. 
A

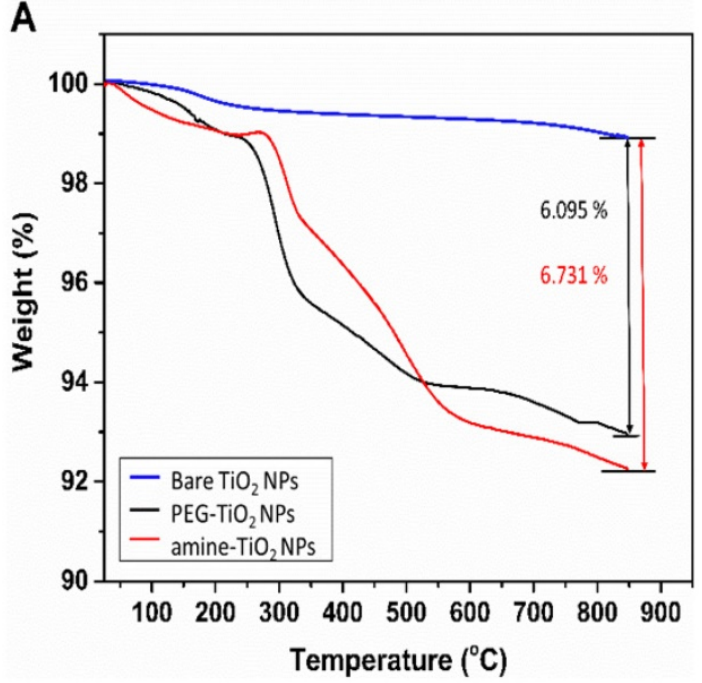

B

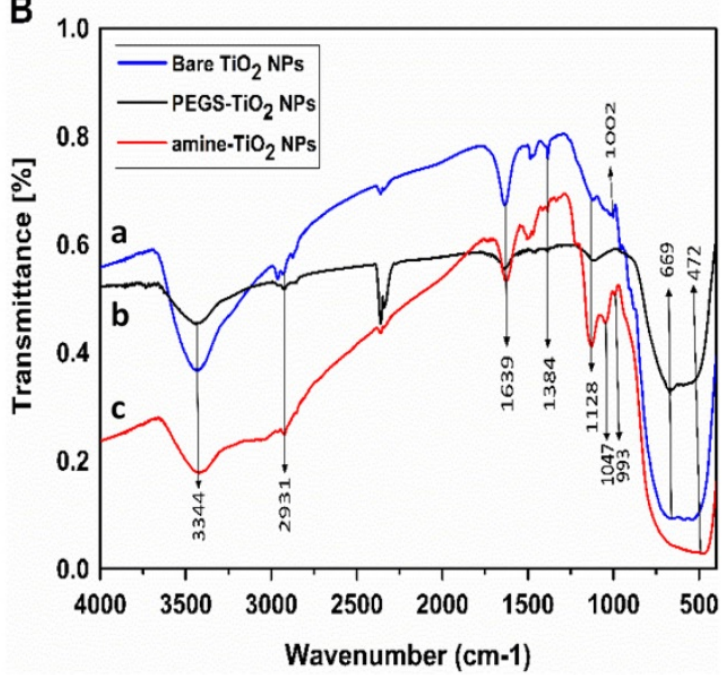

Figure 4. A) Thermogravimetric curves recorded at a heating rate of $10{ }^{\circ} \mathrm{C} / \mathrm{min}$ in a nitrogen flow. B) FTIR spectra for bare and surface functionalised TiO $2-\mathrm{NPs}$

A
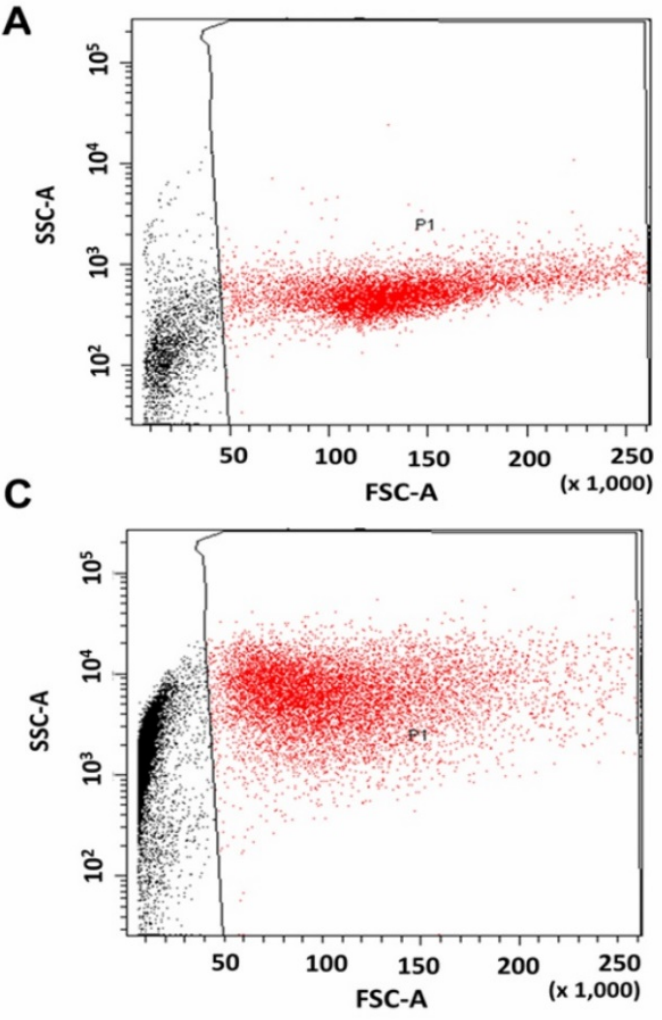

B
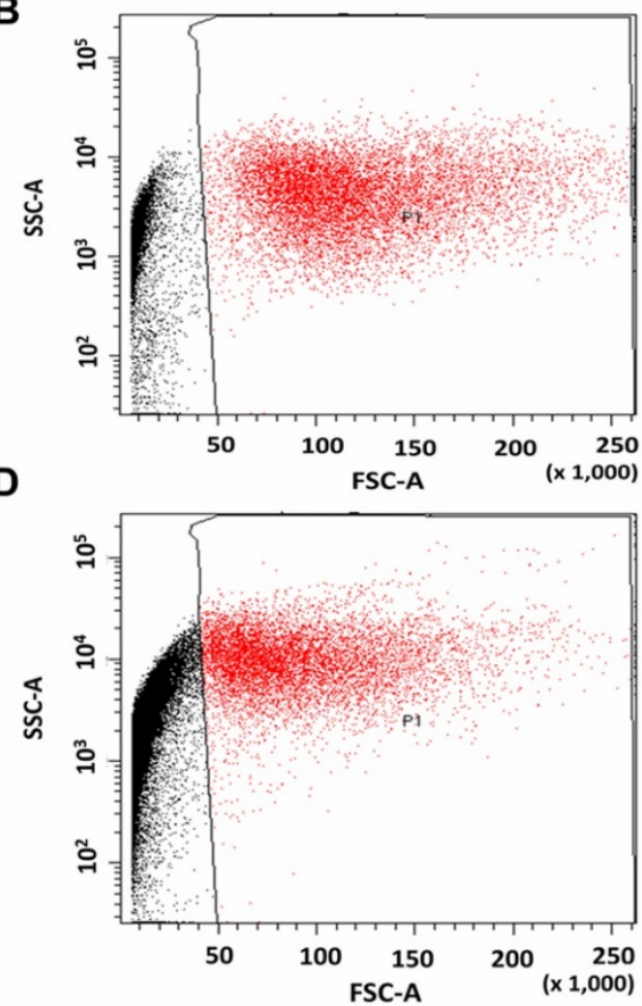

Figure 5. Flow cytometry scatter plots of $\mathrm{HaCaT}$ cells. A) Without treatment (control), and treated with, B) $0.5, \mathrm{C}) 1$ and, D) $4 \mathrm{mM} \mathrm{TiO}_{2}-\mathrm{NP}$ solutions.

\section{$\mathrm{TiO}_{2}$-NPs Association with Cells}

Flow-cytometry (FCM) was used to observe the cellular association and/or uptake of NPs by taking advantage of the increased visible-light scattering caused by $\mathrm{TiO}_{2}-\mathrm{NPs}$, relative to the mostly translucent cellular environment (Figure 5). HaCaT cells were exposed to amine functionalised $\mathrm{TiO}_{2}-\mathrm{NP}$ concentrations of $0.5,1$ and $4 \mathrm{mM}$ for $24 \mathrm{~h}$. Untreated cells were used as controls. In treated samples, forward scatter (x-axis) remained unchanged (suggesting no change in object size), whereas side-scatter (y-axis) increased by $945 \%(0.5 \mathrm{mM}), 1307$ $\%(1 \mathrm{mM})$ and $2045 \%(4 \mathrm{mM})$ versus the control. This suggests a strong association between the cells and the NPs in the treated samples, though it does not distinguish between NPs within the cells and those bound to the cell surface. 


\section{Cytotoxicity of $\mathrm{TiO}_{2}-\mathrm{NPs}$}

HaCaT and DU145 cell lines were exposed to amine functionalised $\mathrm{TiO}_{2}-\mathrm{NPs}$ at concentrations ranging from 1 to $8 \mathrm{mM}$ for 24,48 and $72 \mathrm{~h}$ to investigate the kinetic tolerance of these cell lines to $\mathrm{TiO}_{2}$-NPs. Cell viability was measured via MTS assays. Cell viability was expressed as a percentage of treated cultures to untreated controls. The results indicated that $\mathrm{TiO}_{2}-\mathrm{NPs}$ were nontoxic up to $4 \mathrm{mM}$ post $72 \mathrm{~h}$ of treatment (Figure 6A). When cells were exposed to higher concentrations (up to $8 \mathrm{mM}$ ), viability remained constant (100\%) after $24 \mathrm{~h}$ (Figure 6B).

\section{Dose Enhancement and Radiosensitivity Induced by $\mathrm{TiO}_{2}-\mathrm{NPs}$}

\section{Low Energy “kV” X-Ray Irradiation}

The radiation enhancement caused by $\mathrm{TiO}_{2}-\mathrm{NPs}$ at $\mathrm{kV}$ energy $\mathrm{X}$-rays of the type used in superficial $X$-ray beams was determined by phantom (PRESAGE ${ }^{\circledR}$ dosimeter) and in vitro cell based studies. PRESAGE ${ }^{\circledR}$ dosimeter can be easily loaded with NPs during manufacture, and we have previously used this approach [17]. Dose enhancement in PRESAGE ${ }^{\circledR}$ dosimeters for the first time loaded with and without PEG functionalised $\mathrm{TiO}_{2}-\mathrm{NPs}$ is obtained by measuring the change in optical density $(\triangle \mathrm{OD})$ after irradiation, using a spectrophotometer. The OD of the dosimeter without nanoparticles (control) was subtracted from the $\mathrm{TiO}_{2}$-NPs doped dosimeters. The dosimeters were irradiated with $80 \mathrm{kV}$ energy X-rays. $\mathrm{TiO}_{2}-\mathrm{NPs}$ concentrations of $0,0.5$ and $1 \mathrm{mM}$ were used to investigate NP dose enhancement. It was not possible to go beyond a $1 \mathrm{mM}$ concentration of $\mathrm{TiO}_{2}-\mathrm{NPs}$ (or $4 \mathrm{mM} \mathrm{TiO} \mathrm{T}_{2}-\mathrm{NPs}$ specifically in the in

A

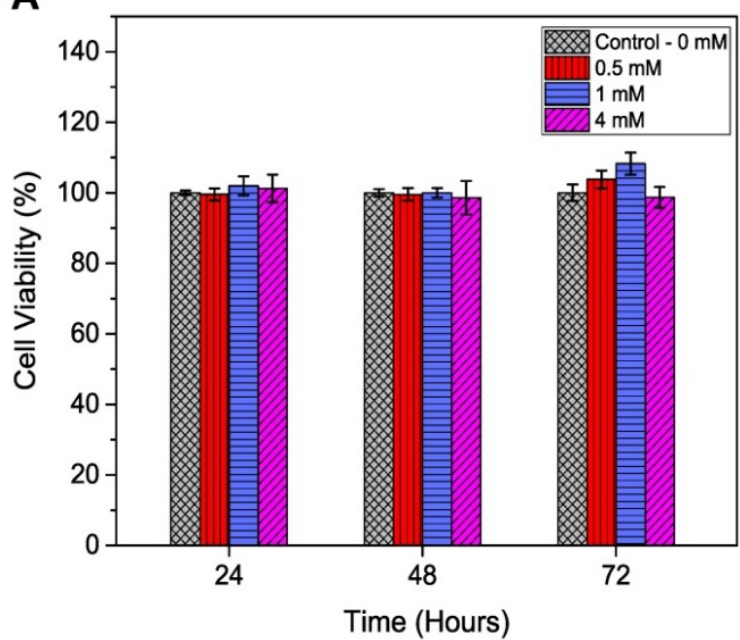

vitro study), as this high concentration caused shelding of the incident light passing through the PRESAGE ${ }^{\circledR}$ dosimeter, resulting in spectrophotometer artifacts during the scanning procedure. The dose enhancement factor (DEF) was measured as a ratio between the slope of the curve of the $\mathrm{TiO}_{2}-\mathrm{NPs}$ doped dosimeters OD and the slope of the curve of the undoped dosimeters OD (control). The average size of the NPs (30 nm in diameter) helps to eliminate any size effects as previously stated [17]. The $\Delta \mathrm{OD}$ of the dosimeters versus the applied radiation dose is shown in Figure 7A. An excellent linear correlation coefficient $\left(\mathrm{R}^{2}>0.99\right)$ for the dose response was observed for both the control and NP doped dosimeters over the applied radiation dose range. This linearity indicated that the $\mathrm{TiO}_{2}-\mathrm{NPs}$ were homogeneously dispersed throughout the dosimeter. Dose enhancement factors of 1.12 and 1.40 (i.e., an increase of 12 and $40 \%$, respectively) was calculated for NP concentrations of 0.5 and $1 \mathrm{mM}$, respectively (Table 2).

Table 2. DEFs for $\mathrm{TiO}_{2}-\mathrm{NPs}$ in $\mathrm{PRESAGE}^{\circledR}$ dosimeter studies and in vitro cell studies at $80 \%$ cell survival.

\begin{tabular}{|c|c|c|c|c|c|}
\hline \multirow[t]{2}{*}{ Energy } & \multirow{2}{*}{\multicolumn{2}{|c|}{ Study \& test type }} & \multicolumn{3}{|c|}{$\mathrm{TiO}_{2}-\mathrm{NP}$ concentration $(\mathrm{mM})$} \\
\hline & & & $0.5 \mathrm{mM}$ & $1 \mathrm{mM}$ & $4 \mathrm{mM}$ \\
\hline \multirow{5}{*}{$80 \mathrm{kV}$} & \multicolumn{2}{|c|}{ PRESAGE® } & 1.12 & 1.40 & ------- \\
\hline & \multirow{2}{*}{ HaCaT } & MTS & 1.21 & 1.57 & 1.70 \\
\hline & & Clonogenic & 1.17 & 1.34 & 1.56 \\
\hline & \multirow[b]{2}{*}{ DU145 } & MTS & 1.27 & 1.45 & 1.77 \\
\hline & & Clonogenic & 1.21 & 1.40 & 1.68 \\
\hline \multirow{5}{*}{$6 \mathrm{MV}$} & \multicolumn{2}{|c|}{ PRESAGE® } & 1.04 & 1.03 & ------- \\
\hline & \multirow{2}{*}{ HaCaT } & MTS & 1.09 & 1.19 & 1.50 \\
\hline & & Clonogenic & 1.13 & 1.18 & 1.37 \\
\hline & \multirow{2}{*}{ DU145 } & MTS & 1.14 & 1.26 & 1.67 \\
\hline & & Clonogenic & 1.10 & 1.19 & 1.43 \\
\hline
\end{tabular}

B

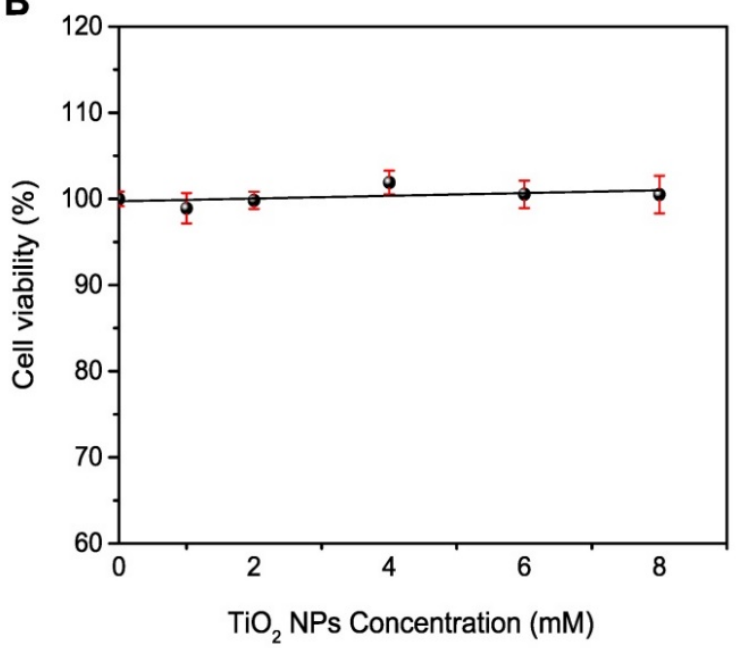

Figure 6. Cell viability for $\mathrm{HaCaT}$ cells exposed to $\mathrm{TiO}_{2}-\mathrm{NPs}$. A) Time dependence. B) Concentrations dependence at $24 \mathrm{~h}$. Similar results were observed with DU145 cells. 
A

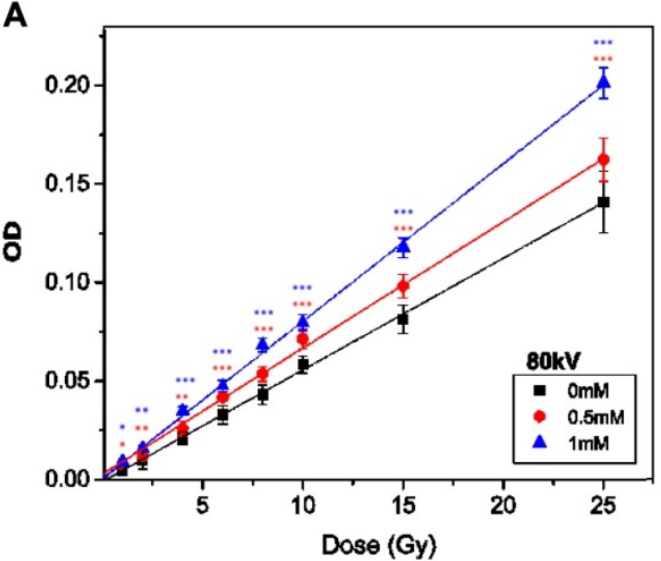

B

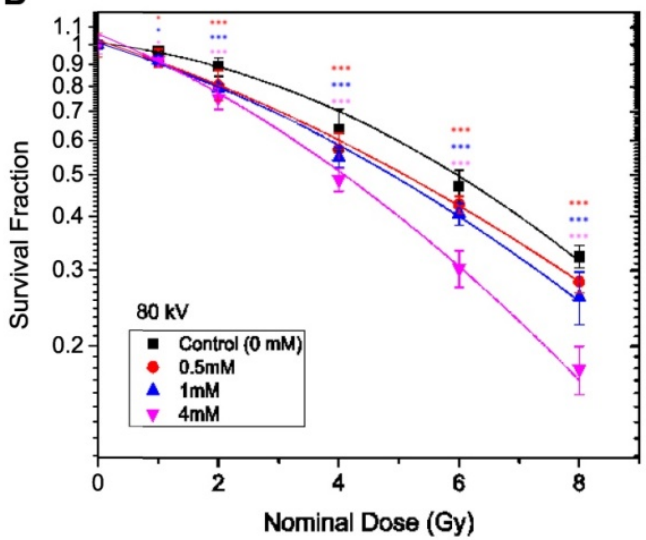

D

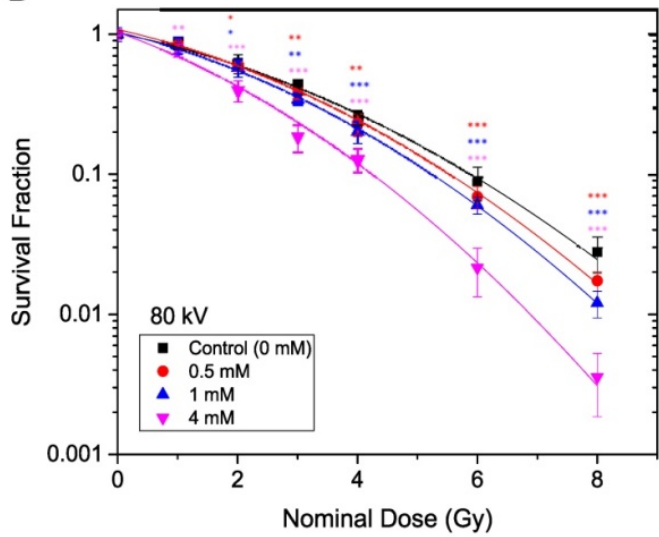

C

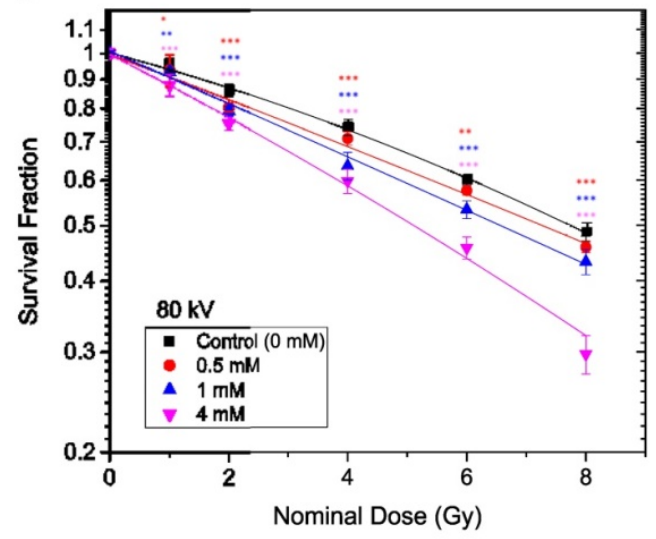

E

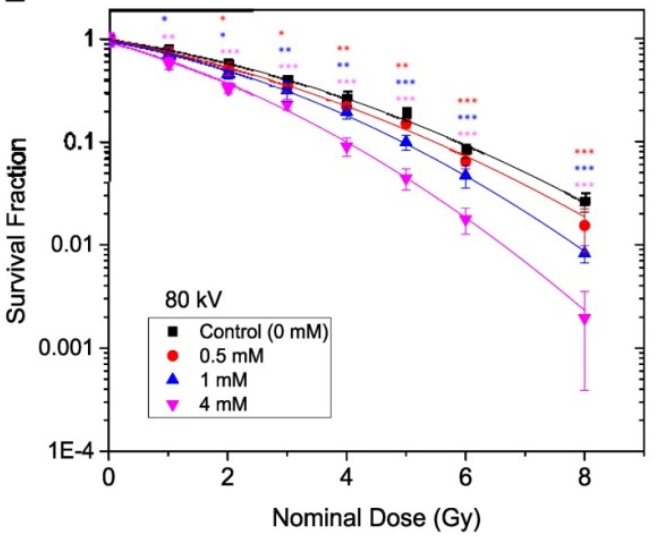

Figure 7. Dose enhancement at various concentrations of $\mathrm{TiO}_{2}-\mathrm{NPs}$ for $80 \mathrm{kV}$ X-ray beam. A) Recorded $\triangle \mathrm{OD}$ as a function of applied radiation dose for PRESAGE dosimeter. B, D) Survival curves for $\mathrm{HaCaT}$ cell employing MTS and clonogenic assays, respectively. C, E) Survival curves for DU145 cell lines tested by MTS and clonogenic assays, respectively. The errors are standard error mean from three independent experiments (mean \pm SEM, $n=3$ ). The curves are fitted with linear quadratic model and DEF was obtained at $80 \%$ survival. Results are considered to be statistically significant at $p$ values of less than $0.05(* p<0.05$, $* * p<0.01, * * * p$ $<0.001)$.

In the in vitro study, HaCaT and DU145 cells were utilised to investigate the radiosensitivity effects of $\mathrm{TiO}_{2}-\mathrm{NPs}$ at concentrations of $0.5,1$ and $4 \mathrm{mM}$. Clonogenic and MTS assays were employed for determination of the DEF. Data were plotted as log \% survival fraction vs nominal dose and fitted with a linear quadratic model. The survival curves with and without $\mathrm{TiO}_{2}$-NPs are displayed in Figures 7B-E, which shows the effects of $\mathrm{TiO}_{2}-\mathrm{NPs}$ concentrations for radiation doses of $0-8 \mathrm{~Gy}$ at $80 \mathrm{kV}$ on cell survival. The DEFs are estimated as a ratio of the control survival fraction to the $80 \%$ survival fraction of treated cells with $\mathrm{TiO}_{2}-\mathrm{NPs}$. The DEFs are extrapolated for both cell lines at $80 \%$ survival and results indicated survival ranged from $70-77 \%$ for MTS assays and 56-68 \% for clonogenic assays with a $\mathrm{TiO}_{2}$-NPs concentration of $4 \mathrm{mM}$ (Table 2). 


\section{High Energy “MV” X-Ray Irradiation}

The methods described in the previous section ( $\mathrm{kV}$ X-Ray Irradiation), were repeated to measure the radiosensitivity of $\mathrm{TiO}_{2}$-NPs in vitro and in phantom with $6 \mathrm{MV}$ X-ray beams. A slight, non-significant dose enhancement was detected with the PRESAGE $^{\circledR}$ dosimeter (Figure 8A). However, the in vitro study (under the same conditions) revealed significant radiosensitisation of $\sim 50-67 \%$ following the MTS assays and $37-43 \%$ from the Clonogenic assays at $\mathrm{TiO}_{2}-\mathrm{NPs}$ concentration of $4 \mathrm{mM}$ (Table 2). The survival curves with and without $\mathrm{TiO}_{2}-\mathrm{NPs}$ are displayed in Figures 8B-E.

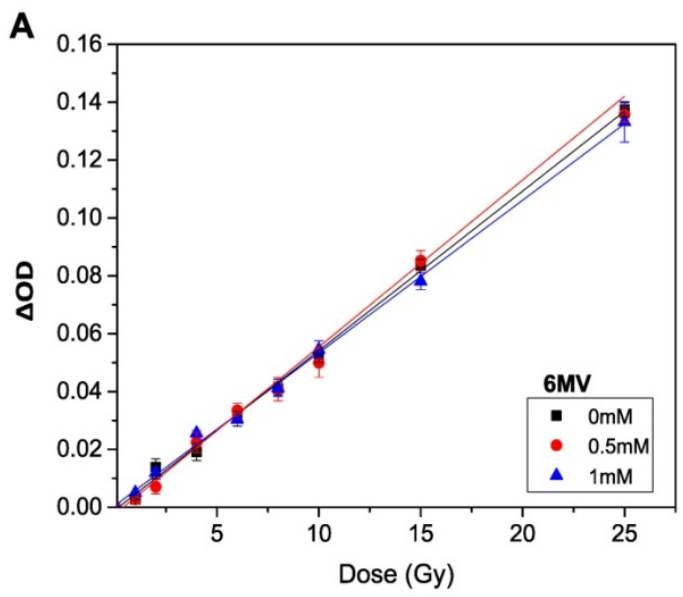

B

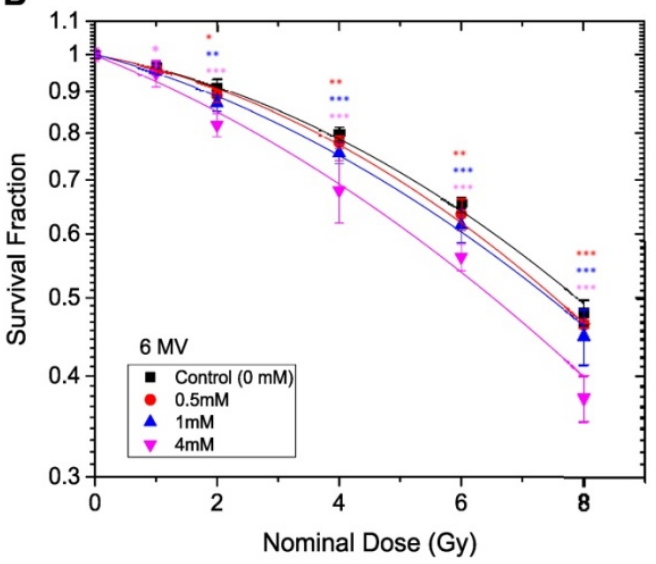

D

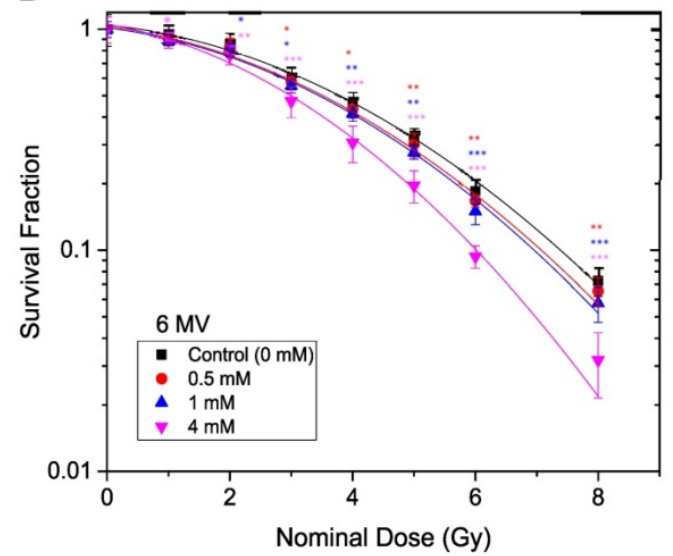

C

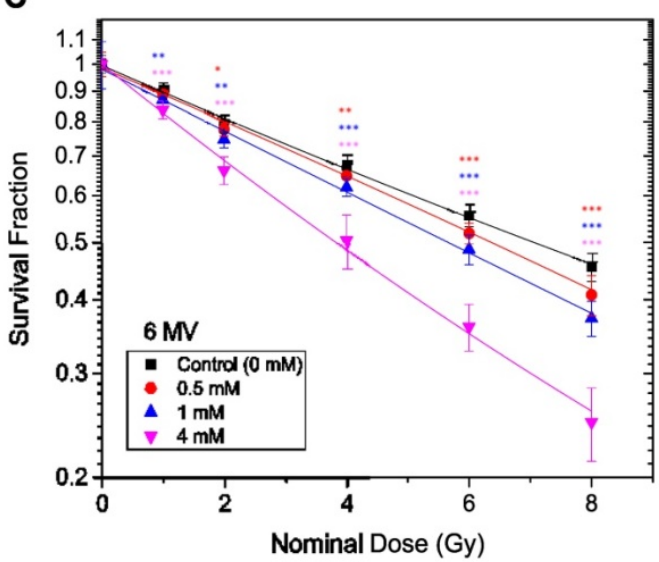

E

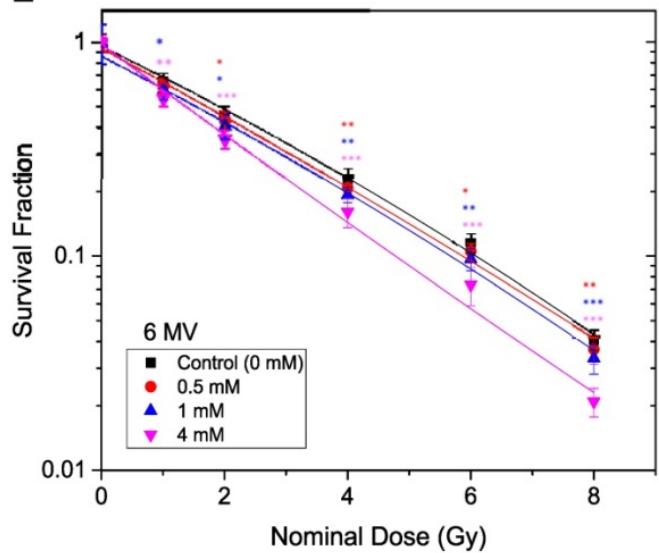

Figure 8. Dose enhancement at various concentrations of $\mathrm{TiO}_{2}-\mathrm{NPs}$ for $6 \mathrm{MV}$ X-ray beams. A) Recorded $\triangle \mathrm{OD}$ as a function of applied radiation dose for PRESAGE dosimeter. B, D) Survival curves for $\mathrm{HaCaT}$ cell employing MTS and clonogenic assays, respectively. C, E) Survival curves for DU145 cells measured by MTS and clonogenic assays, respectively. The errors are standard error mean from three independent experiments (mean \pm SEM, $n=3$ ). The curves are fitted with linear quadratic model and DEF was obtained at $80 \%$ survival. Results are considered to be statistically significant at $p$ values of less than $0.05(* p<0.05$, ** $p<0.01, * * * p$ $<0.001)$. 


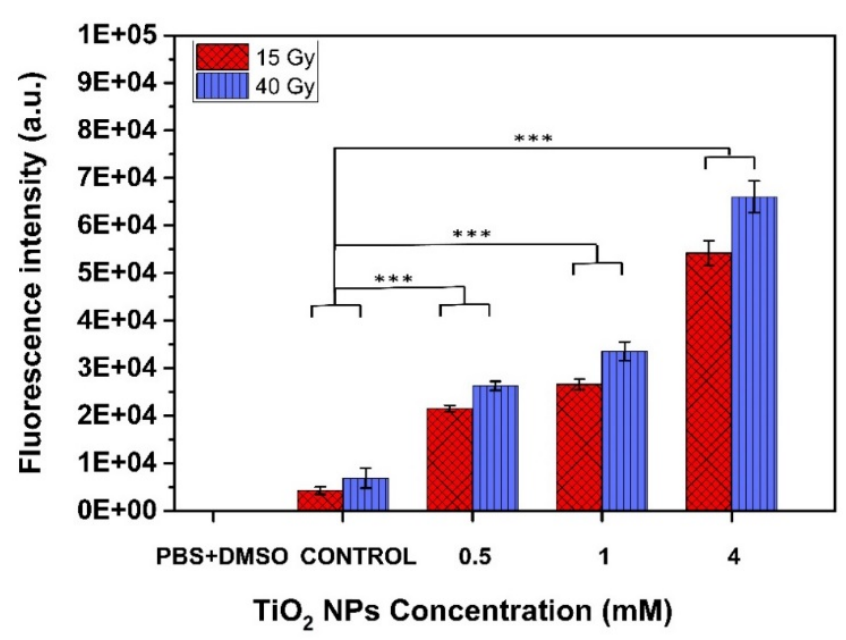

Figure 9. ROS generated from $\mathrm{TiO}_{2}-\mathrm{NPs}$, detected by DCFDA after exposed to $6 \mathrm{MV}$ X-ray beam at radiation doses of (15 and 40) Gy. Results are considered to be statistically significant at $p$ values of less than $0.05(* p<0.05$, $* * \mathrm{p}<0.01$, *** $\mathrm{p}<0.001$ ).

\section{Generation of ROS by $\mathrm{TiO}_{2}-\mathrm{NPs}$}

Figure 9 shows reactive oxygen species (ROS) detected after $6 \mathrm{MV}$ beam exposure of aqueous solutions without (control) and with $\mathrm{TiO}_{2}-\mathrm{NPs}$, as measured using 2', $7^{\prime}$-dichlorofluorescin diacetate (DCFDA), a fluorogenic dye that measures primarily hydroperoxide ROS activity [24]. The use of PBS+DMSO solution was to show that there was no contribution of these solutions in the ROS generation. The results clearly show that ROS generation was dependent on $\mathrm{TiO}_{2}-\mathrm{NPs}$ concentration. This illustrates that biochemical effects were a key factor for enhancing the cellular radiosensitivity, which would be an important consideration in radiosensitivity measurements.

\section{Discussion}

The synthesised $\mathrm{TiO}_{2}-\mathrm{NPs}$ by the hydrolysis of titanium chloride $\left(\mathrm{TiCl}_{4}\right)$ in sulphuric acid $\left(\mathrm{H}_{2} \mathrm{SO}_{4}\right)$ at $50{ }^{\circ} \mathrm{C}$ is a typical synthesis method for achieving uniform nano-crystalline structures with a highly pure phase of titania anatase [17]. Data from the $\mathrm{TiO}_{2}-\mathrm{NPs}$ calcined at $600{ }^{\circ} \mathrm{C}$ indicated that the anatase phase was predominant and no impure phases were observed as indicated in the XRD analysis (Figure 2C). XPS peaks at 458.9, 464.6, and 530.1-533.4 eV are characteristic binding energies of $\mathrm{Ti} 2 \mathrm{p}_{3 / 2}$, Ti2 $\mathrm{p}_{1 / 2}$ and $\mathrm{O} 1 \mathrm{~s}$, respectively, which are indicators of the titanium and oxygen signals in the $\mathrm{TiO}_{2}$ lattice (Figure 2D). The anatase crystal form of $\mathrm{TiO}_{2}$ is preferable as the anatase structure creates more free radicals and has a larger surface area to volume ratio and therefore generates ROS more effectively than other types of $\mathrm{TiO}_{2}-\mathrm{NPs}$ [12-15]. All these features in combination have a high impact on DNA damage leading to cells death during irradiation.

TGA analysis of the functionalised $\mathrm{TiO}_{2}-\mathrm{NPs}$ showed that coatings were $\sim 6 \%$ of the total NP mass (Figure 4A). This indicates that most of the observed dose enhancement or radiosensitisation results from X-ray interaction with the $\mathrm{TiO}_{2}-\mathrm{NPs}$, as the bulk of the particle is mainly composed of $\mathrm{Ti}$ and oxygen atoms. The peaks at 1047 and $1128 \mathrm{~cm}^{-1}$ observed in the FTIR spectra demonstrate that the amino and PEG surface coatings were successfully grafted on the $\mathrm{TiO}_{2}-\mathrm{NPs}$.

The increased side scatter observed in the flow cytometry for $\mathrm{TiO}_{2}-\mathrm{NPs}$ exposed cells (Figure 5) implies close association between the NPs and cells. Though this data does not necessary indicate uptake. Nevertheless, the NPs will still be in close proximity to the nucleus and intracellular uptake may not be an absolute necessity for radiation dose enhancement [17]. Moreover, the radiation generated free radicals and their derivatives can kill the cells by damaging other components of the cells which exists in the cytoplasm. Other in vitro studies do indicate that $\mathrm{TiO}_{2}$-NPs can be internalised by various cell lines [25, 26], and it has been demonstrated that in the absence of cytotoxicity, cells can effectively absorb $\mathrm{TiO}_{2}-\mathrm{NPs}$ to quite high concentrations [27]. The results presented here illustrate that the $\mathrm{TiO}_{2}-\mathrm{NPs}$ were cytocompatible up to concentrations of $8 \mathrm{mM}$; therefore, the concentration ranges of NPs used in vitro in this study were suitable for studying radiosensitasation effects without confounders. Conversely, it is not possible to exceed a $1 \mathrm{mM}$ concentration with many other NPs compositions including gold and bismuth NPs [25, 26].

The results of this study confirm that radiosensitisation at $80 \mathrm{kV}$ is greater than at $6 \mathrm{MV}$ for $\mathrm{X}$-ray energy beams and this supports the work of a large number of investigators for other type of NPs $[27,28]$. The primary difference in the effect of these two energies is the domination of the likelihood of type of interaction. At low energies $(80 \mathrm{kV})$, the dominant process of interaction is the photoelectric effect (PE), i.e., absorption of an incident $X$-ray photon completely and ejection of secondary electrons from the inner shells of the target atom. While at high energies (say $6 \mathrm{MV}$ ), the interaction of X-ray photons is mainly through Compton scattering which occurs at the outer shells of the atom and results into a recoil electron and a lower energy photon. Moreover, it is well known that the probability for the photoelectric effect depends strongly on the atomic number (Z). Thus it is anticipated that at $80 \mathrm{kV}$ (where PE is dominant), the interaction of $\mathrm{X}$-ray photons with $\mathrm{Ti}$ atoms in the $\mathrm{TiO}_{2}-\mathrm{NPs}$ will be much higher than the interaction with the tissues. The effective atomic 
number of $\mathrm{TiO}_{2}$ is 18.49 and that of tissue is about 7.4. Therefore, taking the probability of interaction via PE to be dependent on $\mathrm{Z}^{3}$, the ratio of the probability of $\mathrm{PE}$ interaction with $\mathrm{TiO}_{2}-\mathrm{NPs}$ compared to that with tissue will be about 15.6. Even though the concentration of $\mathrm{Ti}$ is relatively low, this extremely high affinity for the PE interaction could cause a greatly increased interaction probability and lead to the generation of copious secondary electrons hence enhancing the radiation effects locally [29]. This extra generation of secondary electrons is reflected in the results of this study, which indicates clearly in both the phantom and in vitro studies that the dose enhancements caused by the inclusion of the $\mathrm{TiO}_{2}$-NPs were much higher at low energies $(80 \mathrm{kV})$ compared to those measured at high energies (6 MV).

The other point of interest in the results is the observed differences in dose enhancement between the phantom (dosimeter) and cell culture studies, especially at high energies (6 MV). The addition of $\mathrm{TiO}_{2}$-NPs slightly increased the physical density of the systems, while reducing the density of the free electrons - this is due to the $\mathrm{TiO}_{2}-\mathrm{NPs}$ free electron density being about $2.86 \times 10^{23} \mathrm{e} \mathrm{cm}^{-3}$, whereas in tissue it is $3.34 \times 10^{23} \mathrm{e} \mathrm{cm}^{-3}$. This will result in a slight reduction in the density of free electrons when $\mathrm{TiO}_{2}-\mathrm{NPs}$ are present in the target. Thus in absolute terms, there is no significant physical dose enhancement with the $6 \mathrm{MV}$ beam and this is what the PRESAGE $^{\circledR}$ dosimeter study confirmed. The slight $4 \%$ dose enhancement detected with the $6 \mathrm{MV}$ beam is likely to originate from the PE contribution, as the energy spectrum of the MV beam shows some residual low energy and PEs, which have been previously observed with Au NPs [30].

There is clearly some disagreement between the phantom and in vitro studies in regards to the level of radiosensitisation. The cell studies showed higher enhancements in radiosensitivity than the phantom dosimeters (compared in Figures 7 and 8). This can be attributed to the PRESAGE ${ }^{\circledR}$ dosimeters being only able to detect electron free radicals directly generated (the physical effect) and being not suited to the generation of ROS due to a lack of free water molecules. Conversely, cells can be affected by a host of the biochemical events, such as ROS generation, which are additional stresses above those generated by secondary electrons (Figure 10), and thus result in greater radiosensitivity. This specific point was illustrated in this study through three sets of experiments measuring ROS levels generated by radiation in the presence or absence of $\mathrm{TiO}_{2}-\mathrm{NPs}$ (Figure 9). The common ROS generated by $\mathrm{TiO}_{2}-\mathrm{NPs}$ when exposed to ionizing radiation are superoxide $\left(\mathrm{O}_{2}^{-}\right)$, hydroxyl radical $(\mathrm{OH})$, hydrogen peroxide
$\left(\mathrm{H}_{2} \mathrm{O}_{2}\right)$, and singlet oxygen $\left({ }^{1} \mathrm{O}_{2}\right)$ [30]. As the fluorescence probe (DCFDA) does not discriminate between different forms of ROS, it is not possible to identify a specific ROS that is responsible for the produced oxidative stress observed in these studies. The slight variations observed between cells result could be due to the difference in their response to the radiations and to the inclusion of the $\mathrm{TiO}_{2}-\mathrm{NPs}$.

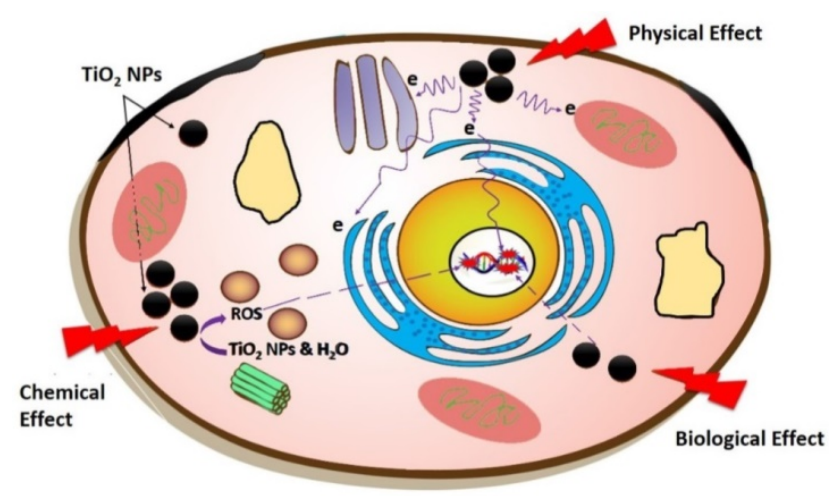

Figure 10. Schematic diagram showing interaction of $\mathrm{X}$-ray with $\mathrm{TiO}_{2}-\mathrm{NPs}$ result in the production of secondary electrons and ROS through physical and biochemical effects.

In conclusion, these results clearly show that $\mathrm{TiO}_{2}$-NPs can significantly radio-sensitise cells in culture. In particular, the $\mathrm{TiO}_{2}-\mathrm{NPs}$ are more sensitive for the cells than the phantom at MV X-ray beams, which are most commonly used in radiotherapy. The radiosensitisation caused by the NPs most likely results from the generation of ROS that are highly effective in cell killing, as opposed to high atomic mass effects that are only likely to be prominent at kilovoltage energies. The $\mathrm{TiO}_{2}-\mathrm{NPs}$ were also shown to be cytocompatible and therefore larger concentrations can potentially be loaded into cells and tissues prior to irradiation. The discrepancy between the levels of radiosensitisation caused by the same concentration of particles as measured in vitro compared to phantoms is attributable to ROS generation, which is not present in phantoms, but is highly detrimental to cells. Further investigations will involve expansion of these measurements using other radiation beams, particularly the effects of charged particles. In addition, testing radiosensitisation induced by $\mathrm{TiO}_{2}-\mathrm{NPs}$ in animal models with potential to be applied in future clinical radiotherapy applications. Moreover, $\mathrm{TiO}_{2}$ has been documented to be potentially a suitable radiologic contrast agent [30], hence after proving its value in enhancing the radiation effects at the targets through this research renders it to be a theranostic agent with dual effects simultaneously if it is in radiation targets. 


\section{Abbreviations}

$\mathrm{TiO}_{2}$ : Titanium Dioxide; NPs: Nanoparticles; HaCaT: Human Keratinocyte cell line; DU145: Prostate cancer cell line; ROS: Reactive Oxygen Species; $\cdot \mathrm{OH}$ : Hydroxyl Radicals; PE: Photoelectric Effect; APTS: AminoPropyl TrimethoxySilane; PEGTS: Poly (Ethylene Glycol) TrimethoxySilane; LMG: Leucomalachite Green; DBTDL: Dibutyltin Dilaurate; SXRT: Superficial X-Ray Therapy; $\triangle \mathrm{OD}$ : changes in optical density; DCFDA: Dichlorofluorescin Diacetate; DEF: Dose Enhancement Factor.

\section{Acknowledgments}

The Authors gratefully acknowledge the support of the School of Health and BioMedical Science, RMIT University. We would also like to thank Frank Gagliardi and the Alfred Health Radiation Oncology, Alfred Health, Melbourne, Australia for providing facilities and with irradiation assistance. We acknowledge Sioe See Volaric the laboratory supervisor at the School of Chemistry, The University of Melbourne, Melbourne, Australia and Clare Smith from Discipline of Medical Radiation, RMIT University for their valuable help with NPs characterisation.

\section{Competing Interests}

The authors have declared that no competing interest exists.

\section{References}

1. Connell PP, Hellman S. Advances in radiotherapy and implications for the next century: a historical perspective. Cancer research. 2009; 69: 383-92.

2. Bhide S, Nutting C. Recent advances in radiotherapy. BMC medicine. 2010; 8 : 1.

3. Begg AC, Stewart FA, Vens C. Strategies to improve radiotherapy with targeted drugs. Nature Reviews Cancer. 2011; 11: 239-53.

4. Jain S, Hirst D, O'sullivan J. Gold nanoparticles as novel agents for cancer therapy. The British journal of radiology. 2014.

5. Oronsky BT, Knox SJ, Scicinski J. Six degrees of separation: the oxygen effect in the development of radiosensitizers. Translational oncology. 2011; 4: 189-98.

6. Regulla D, Hieber L, Seidenbusch M. Physical and biological interface dose effects in tissue due to X-ray-induced release of secondary radiation from metallic gold surfaces. Radiation research. 1998; 150: 92-100.

7. M. Herold ID, CC Stobbe, RV Iyer, JD Chapman, D. Gold microspheres: a selective technique for producing biologically effective dose enhancement. International journal of radiation biology. 2000; 76: 1357-64.

8. Hainfeld JF, Slatkin DN, Smilowitz HM. The use of gold nanoparticles to enhance radiotherapy in mice. Physics in medicine and biology. 2004; 49: N309.

9. Zhang X, Xing JZ, Chen J, Ko L, Amanie J, Gulavita S, et al. Enhanced radiation sensitivity in prostate cancer by gold-nanoparticles. Clinical \& Investigative Medicine. 2008; 31: 160-7.

10. Rahman $\mathrm{WN}$, Bishara $\mathrm{N}$, Ackerly $\mathrm{T}, \mathrm{He} \mathrm{CF}$, Jackson $\mathrm{P}$, Wong $\mathrm{C}$, et al. Enhancement of radiation effects by gold nanoparticles for superficial radiation therapy. Nanomedicine: Nanotechnology, Biology and Medicine. 2009; 5: 136-42.

11. Luchette M, Korideck H, Makrigiorgos M, Tillement O, Berbeco R. Radiation dose enhancement of gadolinium-based AGuIX nanoparticles on HeLa cells. Nanomedicine: Nanotechnology, Biology and Medicine. 2014; 10: 1751-5.

12. Yin J-J, Liu J, Ehrenshaft M, Roberts JE, Fu PP, Mason RP, et al. Phototoxicity of nano titanium dioxides in $\mathrm{HaCaT}$ keratinocytes - generation of reactive oxygen species and cell damage. Toxicology and applied pharmacology. 2012; 263: 81-8.
13. Jin C, Tang Y, Yang FG, Li XL, Xu S, Fan XY, et al. Cellular toxicity of TiO2 nanoparticles in anatase and rutile crystal phase. Biological trace element research. 2011; 141: 3-15.

14. Townley HE, Kim J, Dobson PJ. In vivo demonstration of enhanced radiotherapy using rare earth doped titania nanoparticles. Nanoscale. 2012; 4: 5043-50.

15. Babaei M, Ganjalikhani M. The potential effectiveness of nanoparticles as radio sensitizers for radiotherapy. Bioimpacts. 2014; 4: 15.

16. Jiang J, Oberdörster G, Elder A, Gelein R, Mercer P, Biswas P. Does nanoparticle activity depend upon size and crystal phase? Nanotoxicology. 2008; 2: 33-42.

17. Li W, Zeng T. Preparation of $\mathrm{TiO} 2$ anatase nanocrystals by $\mathrm{TiCl} 4$ hydrolysis with additive $\mathrm{H} 2 \mathrm{SO} 4$. PloS one. 2011; 6: e21082.

18. Gradzik B, El Fray M, Wisniewska E. Surface modification of $\mathrm{TiO} 2$ and $\mathrm{SiO} 2$ nanoparticles for application in polymeric nanocomposites. Chemik. 2011; 65: 621-6.

19. Zhao J, Milanova M, Warmoeskerken MM, Dutschk V. Surface modification of TiO 2 nanoparticles with silane coupling agents. Colloids and surfaces A: Physicochemical and engineering aspects. 2012; 413: 273-9.

20. Sabzi M, Mirabedini S, Zohuriaan-Mehr J, Atai M. Surface modification of TiO 2 nano-particles with silane coupling agent and investigation of its effect on the properties of polyurethane composite coating. Progress in Organic Coatings. 2009; 65: 222-8.

21. Adamovics J, Maryanski M. Characterisation of PRESAGETM: A new 3-D radiochromic solid polymer dosemeter for ionising radiation. Radiation protection dosimetry. 2006; 120: 107-12.

22. Alqathami M, Adamovics J, Benning R, Blencowe A. An investigation into ultra-sensitive substituted leucomalachite dye derivatives for use in the PRESAGE® dosimeter. Journal of Physics: Conference Series: IOP Publishing; 2013. p. 012034.

23. Lappalainen K, Jääskeläinen I, Syrjänen K, Urtti A, Syrjänen S. Comparison of cell proliferation and toxicity assays using two cationic liposomes. Pharmaceutical research. 1994; 11: 1127-31.

24. Promega C. $96{ }^{\circledR}$ AQueous One Solution Cell Proliferation Assay. Technical Bulletin. 2005

25. Zhao Y, Howe JL, Yu Z, Leong DT, Chu JJH, Loo JSC, et al. Exposure to titanium dioxide nanoparticles induces autophagy in primary human keratinocytes. Small. 2013; 9: 387-92.

26. Kenzaoui BH, Bernasconi CC, Guney-Ayra S, Juillerat-Jeanneret L. Induction of oxidative stress, lysosome activation and autophagy by nanoparticles in human brain-derived endothelial cells. Biochemical Journal. 2012; 441: 813-21.

27. Lopes VR, Loitto V, Audinot J-N, Bayat N, Gutleb AC, Cristobal S. Dose-dependent autophagic effect of titanium dioxide nanoparticles in human HaCaT cells at non-cytotoxic levels. Journal of nanobiotechnology. 2016; 14: 1.

28. Mirjolet $\mathrm{C}$, Papa A, Créhange G, Raguin O, Seignez C, Paul C, et al. The radiosensitization effect of titanate nanotubes as a new tool in radiation therapy for glioblastoma: a proof-of-concept. Radiotherapy and Oncology. 2013; 108: 136-42.

29. Khan FM, Gibbons JP. Khan's the physics of radiation therapy: Lippincott Williams \& Wilkins; 2014.

30. Rahman WN, Wong CI, Ackerly T, Yagi N, Geso M. Polymer gels impregnated with gold nanoparticles implemented for measurements of radiation dose enhancement in synchrotron and conventional radiotherapy type beams. Australasian Physical \& Engineering Sciences in Medicine. 2012; 35: 301-9. 